\title{
Motivation of Traditional Grammar School Pupils and Pupils of Waldorf Grammar School
}

\author{
Dominika Doktorová, Kristína Járosiová \\ The University of Ss. Cyril and Methodius (UCM), Trnava, Slovakia
}

\begin{abstract}
The aim of the research was to identify the sources of motivation of pupils of traditional elementary schools and a Waldorf primary school to learn and to compare the results. The research sample consisted of students from a Waldorf school and traditional schools. There were 51 pupils from a Waldorf School and 103 pupils from a primary school. The selected group of pupils was in the age range between 11 and 16 years. The sources of pupil's motivation for learning were verified by the first two chapters of DMŠ questionnaire. The first chapter focuses on student's achievement motivation and the second chapter is designed for the creation of hierarchy of motivational aspects. This paper points out a statistically important difference in pupil's need to avoid failure. The avoidance of failure appeared to be a more important factor for traditional grammar school students than for pupils of Waldorf Grammar School. The thesis points out that the need to achieve their goals in perspective is considered to be the most significant learning motivator for students of both primary school types. Waldorf school pupils also showed a higher need for their own development.
\end{abstract}

Keywords: motivational aspect, achievement motivation, Waldorf Grammar School's teaching approach

\section{Introduction}

Pupil's motivation for learning is an important factor which affects the results of the educational process (Pavelková, 2002). It influences pupils' attitude towards learning, their ability to successfully cope with school demands and their general study performance (Pavelková, 2002). Every pupil is motivated to do their schoolwork. Existing inter-individual motivational differences are affected by pupils' preferred values. These dominating values work as a motivational education source (Veselský, 2010). Hrabal, Man, and Pavelková (1989) differentiate between internal and external sources of pupils' motivation. The internal motivation sources represent people's needs (Nakonečný, 2004). Hrabal and Pavelková (2010) distinguish 5 main needs, which motivate the pupil to do their school activities. Firstly, it is the recognition need, which means that a child has an instinctive need to discover their surroundings (Čáp, 1993; Deci, Ryan, \& Williams, 1996; Pavelková, 2002; Ryan \& Deci 2000). Secondly, there are social needs, which Hrabal (1978) divides into a socially oriented motivational aspect of earning positive evaluation from its surroundings and the needs to create positive relationships (Vágnerová, 2001). Positive evaluation allows the pupil to feel respect from their classmates and teacher (Veselský, 2010). Positive evaluation and recognition is a significant motivation factor especially at an older school age (Rybárová, 1992). Pupils who need to have positive relationships tend to have 
strong friendships in class and with their teachers (Hrabal, 1978). Performance needs are specified as the pupil's need to try his or her best to achieve comparable or even better performance than the rest of the group. This performance is then positively evaluated (Čáp, 1993). Hrabal (1978) distinguishes a performance motivation stemming from two possible sources. Firstly, the pupil wants to perform well and successfully achieve their own goals. He then tries to accomplish all of the activities even if it becomes more difficult. Secondly, the pupil may be motivated to give better performance by his or her desire to avoid failure (Hrabal, 1978). The need to avoid failure is formed especially in an environment where the pupil is evaluated and compared on a daily basis (Veselský, 2010). The influence of another person on the final evaluation may create a feeling that the pupil is unable to affect the result (Rotter, 1966). This reduces success expectations in future (Weiner et al., 1981). The need to follow moral norms is connected with the pupil's responsibilities for his/her school duties and his/her results, meaning that the pupil understands that he/she has certain obligations that need to be fulfilled (Hrabal, 1988). The pupil's need to form his own future may incite him or her to learning (Hrabal \& Pavelková, 2010). The pupil who recognizes this need understands that the purpose of teaching is actually for his or her future and personal development (Sejčová, 2007). It evolves as a motivational factor in school work at an older school age. The child ends grammar school and thinks about future (Ďurič et al., 1992).

Different incentives become external motivational sources (Sejčová, 2007). Veselský (2010) distinguishes three main external motivational sources that apply to school environment: rewards, punishments and evaluations. Reward is characterized by Čapek (2014) who believes that it is any kind of effect, which the pupil receives for his/her behavior that is positive. A reward is a praise, recognition or social reward or applause (Zelina, 1996). This allows the pupil to be happy and satisfied with his or her performance. On the other hand, punishment is a negative evaluation. The teacher gives it for a behavior that is not wanted (Čapek, 2014). Punishments specified for school environment limit themselves to a denial of benefits, conferring unpleasant work or written and oral rebukes (Veselský, 2010). The most used incentive form is the grading system that works as an evaluation (Zelina, 1996). A significant amount of pupils considers a grade the most valuable reward or punishment. That is because a written evaluation is irreversible (Veselský, 2010). The expectation of either a reward or a punishment for pupil's behavior reduces the level of autoderminition of pupil's schoolwork (Deci et al., 1996). This results in a conception that pupil does not study for his or her own good (Lokšová \& Lokša, 1999).

Waldorf school's concept and methods support a pupil's interest in expanding their horizons and knowledge. They also support positive attitude towards learning in school (Grecmanová \& Urbanovsá, 1996). This concept relies on the motive of individual's freedom. School allows the pupil to individually choose the way to understand his or her surroundings. Teaching methods focus on games, experiments and casual talks. Along this teaching process, singing and musical instruments are used as well. These methods encourage pupil's natural will to learn. They develop intristic motivation (Gorduličová \& Baloha, 2013). Internal motivation is supported also by the method of performance evaluation. The teacher does not use traditional evaluation methods. Up to the seventh grade, pupils are evaluated by word descriptions of either their deficits or their progress (Grecmanová \& Urbanovská, 1996).

Traditional grammar school teaching style is usually direct (Zelina, 1996). Directions, criticism or punishments are normal for standard teaching. School does not provide necessary space for pupil's own initiative (Čáp, 2001). The core of training methods are informative and receptive processes. The pupil 
embraces presented information by reproducing teacher's comments and training through exercises (Jurašková, 2004). The pupil's active motivation factor represents the evaluation of his or her performance on a classification scale. For this reason, pupils usually consider good grades to be their learning priorities. The teaching concept supports pupil's external motivation (Gorduličova \& Baloha, 2013).

Comparative research of teaching impact on motivation at Waldorf and traditional grammar schools is currently only at the first stage of data collection. The research, however, confirms that the pupils studying at a Waldorf school has more positive attitude towards learning in comparison to traditional grammar school students (Pulicarova, 2015). According to Ionova's (2013) analytical evaluation of European comparative researches, Waldorf pupils have a higher interest in learning, more positive attitude towards self-learning and they are motivated to learn for their own good. According to Chvalová (2014), the pupils of a Czech Waldorf school also consider the most frequent motivational factor for English learning to be the need of getting to know new things. On the other hand, traditional grammar school students claimed their primary motivational source to be the sense of responsibility.

\section{Research Intention and Goal}

The Waldorf school concept is based on an effort to provide a child with the most exciting environment in order to prepare the child for his or her future life. One of the main goals of a Waldorf school is the development of healthy motivation. These factors may improve learning process and the overall quality of life. Nowadays there are only a few researches that compare the results of traditional primary schools and a Waldorf school. Besançon, Fenouillet, and Shanklad (2015) focused on the pupil's perceived well-being. The comparative research has still not been conducted especially in comparing the motivational sources and tendency to achieve successful performance or to avoid failure. Therefore our research of this matter was explorative.

The main goal of this research is to compare and explore motivational sources of traditional grammar schools (TGS) and Waldorf Grammar School (WGS). A part of this research is the comparison of tendency to avoid failure and tendency to achieve success. The main goal splited this issue down into smaller goals. Those are as follows:

(1) To find out the hierarchy of motivational aspects for pupils of TGS and WGS;

(2) To find out the level of tendency to achieve successful performance for pupils of TGS and WGS; and

(3) To find out the tendency to avoid failure for pupils of TGS and WGS.

The pedagogical principles typical of traditional grammar schools form mostly the external motivation and Waldorf grammar schools focus on forming the internal pupils' motivation (Rýdl, 1999, as cited in Alexovičová, 2007) formed following hypotheses.

H1: There is a significant statistical difference between achieved score and the need to achieve successful performance of traditional primary schools and Waldorf Grammar Schools.

$\mathrm{H} 2$ : There is a significant statistical difference between achieved score when it comes to avoiding failure in traditional primary schools and Waldorf school.

A part of the research goal is to examine the hierarchy of motivational aspects for both types of schools. Therefore the following research questions were formed:

R.Q. 1: What is the hierarchy of motivational aspects towards learning for traditional grammar school pupils? 
R.Q. 2: What is the hierarchy of motivational aspects towards learning for Waldorf grammar school pupils?

R.Q. 3: What is the difference between hierarchies of motivational aspects for both types of schools?

\section{Research Sample}

The research sample consisted of Bratislava Waldorf Grammar School pupils and three intentionally chosen traditional grammar schools. The three traditional grammar schools are located in Bratislava, Trnava and Sered. The sample consisted of 159 pupils. The parents of five pupils have directly refused to refused to let their children participate in the research. All of them studied at a traditional grammar school. The overall number of pupils actively participating in this research is therefore 154. Fifty-one (33.1\%) were from a Waldorf grammar school and 103 (66.9\%) from a traditional grammar school. These statistics are shown in Figure 1.

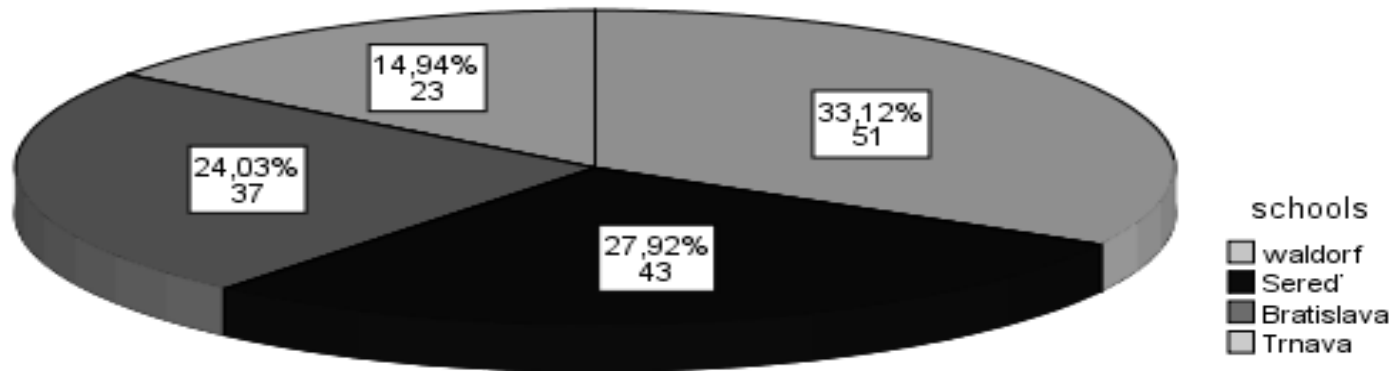

Figure 1. Numbers of students participating (Source: Authors of the thesis).

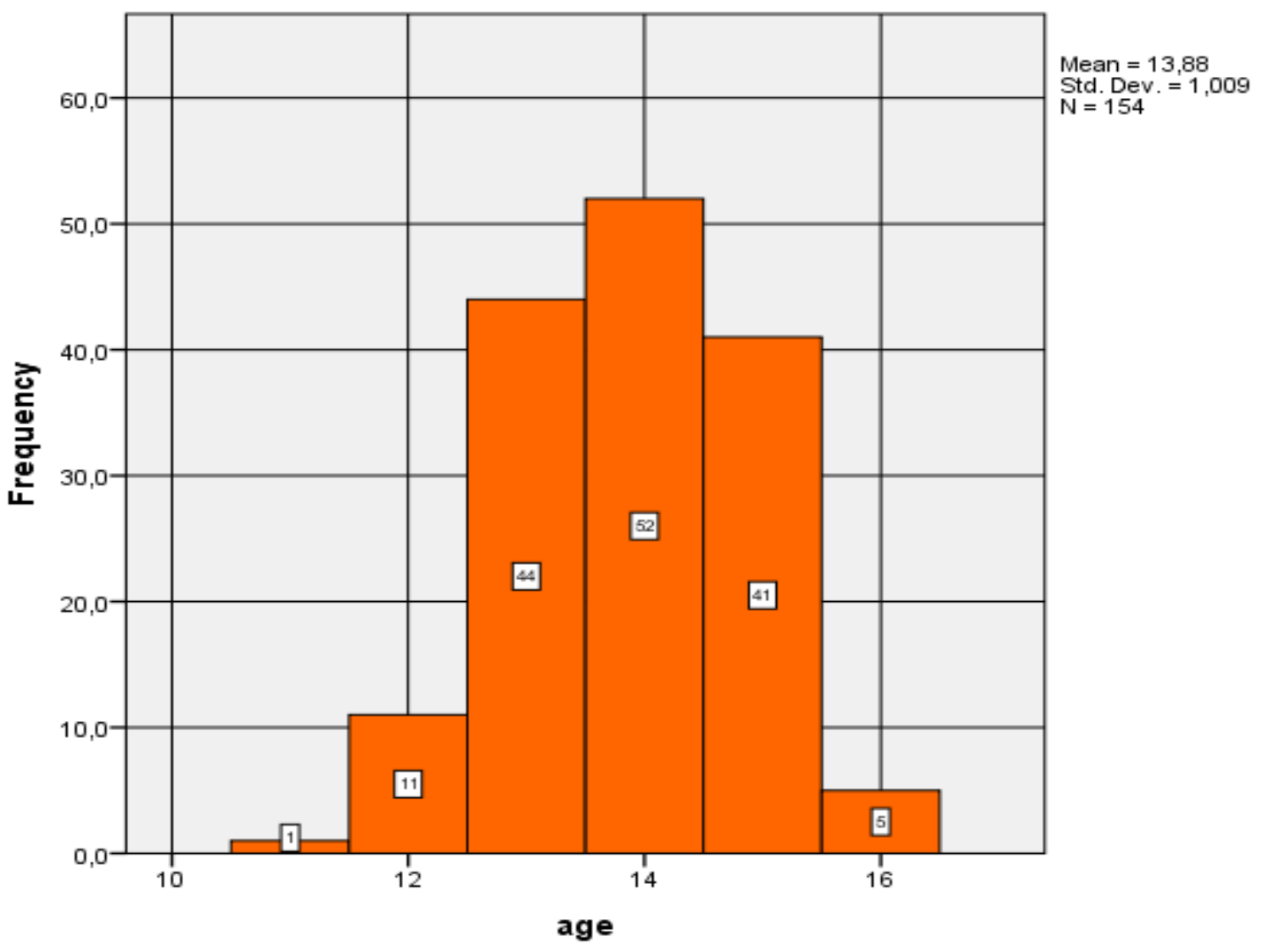

Figure 2. Student age range (Source: Authors of the thesis). 
For this research, we wanted to cooperate with students from the seventh, eighth and ninth grades. The respondents' age ranges from 11 to 16 years old with an average of 13.88 years. The exact numbers are shown in Figure 2. This age range was chosen in the belief that higher grades show a more significant result of a particular teaching approach. The previous plan was about involving students from the eighth and ninth grade, however; since there is only one Waldorf grammar school with a higher education, we also included the seventh grade in order to increase the number of Waldorf school respondents. The exact number of respondents is shown in Figure 2.

\section{Methods}

As a data collection method, a questionnaire was used. Questionnaire QMS (DMŠ) produced by Barqawi and Valovič (2015) was used for this purpose. It consists of three scales with 25 items. The first two scales focus on the achievement motivation measurement and examination of students' motivational hierarchy. These two scales were used also in this research since the goals of this thesis was to find out which motivational aspects dominate for pupils of both types of schools and which on the other hand are not at all important for student's learning. We also wanted to find out whether students need to perform well or have the tendency to avoid failure. This questionnaire allowed finding this information out. The last scale focuses on pupil's low interest in studying and therefore we will not be examining this part.

\section{Data Collection}

The data was collected in all participating schools at the beginning of the year 2016. Before the research was conducted, we contacted legal representatives of the students and explained the conditions and goals of the research in writing. By signing the informational agreement they agreed that their child would participate in this research. At first, we collected also student approvals and so the research cooperated only with students who agreed with the research. We explained to students the conditions and the requirements of research. The research was anonymous and purely voluntary. They were asked to answer the questionnaire honestly and based on their own emotions and feelings. After obtaining a measuring device, the pupils were asked to fill in the header with general information. There was no time limitation for completion of this questionnaire. When there was something unclear, students could ask about it anytime and once the research was conducted, all participating schools were provided with its results.

The analysis of collected data was done through statistical program IBM SPSS Statistics 20. Through this program, we were able to gain basic descriptive statistics of multiplicity, percentage representation, average values and standard outliers. This program was also used for graphs and tables. Furthermore, through this program we compared the collected data from a Waldorf Grammar School and traditional grammar schools. Since in both types of schools there were more than 50 participants, Kolmogor-Smirnov test was used. Normal distribution was not confirmed in factors. Hypotheses concerned with these factors were analyzed in a non-parametric version of Mann-Whitney $U$ test. SPSS program also gathered averages of motivational aspects, which helped us to create a hierarchy of Waldorf grammar school motivational aspects and also those from traditional grammar schools.

\section{Results}

These questionnaires gave us quantitative data. One part of the questionnaire asked about a student's 
motivational hierarchy with respect to learning. Students' motivation was examined with a qualitative research. For the better understanding we provide tables for every with respect to each and every assumption implied.

H1: There is a significant statistical difference in the achieved score and the need to achieve successful performance for students of traditional primary schools and a Waldorf Grammar School.

In our research, we were interested in finding out which type of performance need is important for students studying at above mentioned schools. Firstly, we focused on the descriptive values which students achieved in an attempt to achieve successful performance. These values are shown in Table 1.

Table 1

Descriptive Table of Students' Values to Achieve Performance

\begin{tabular}{cllrrrrl}
\hline & School & Sex & $N$ & Min & Max & $M$ & $S D$ \\
\cline { 2 - 8 } & Waldorf & Girls & 29 & 16 & 28 & 21.21 & 3.155 \\
Successful performance & Sum & Boys & 22 & 6 & 29 & 20.68 & 4.980 \\
& & 51 & 6 & 29 & 20.98 & 4.716 \\
& Traditional & Girls & 49 & 13 & 29 & 20.65 & 4.191 \\
& & Boys & 54 & 10 & 29 & 19.81 & 4.404 \\
\hline
\end{tabular}

Source: Authors of the thesis.

Table 1 shows descriptive values of students' tendencies to achieve successful performance. The lowest value of the need to achieve successful performance through studying was measured for the Waldorf grammar school student. His point value was 6 . The highest point representation was identical for both schools and that was the value of 29. The Waldorf grammar school student's tendency to achieve success in performance averaged at 20.98 with a variation of 4.716 . Traditional grammar school students' tendency to achieve success in performance averaged at 20.21 with a variation of 4.304 .

Table 2

Comparison Levels of Need to Achieve Successful Performance for Students of Waldorf Grammar School and Traditional Grammar Schools

\begin{tabular}{llrlll}
\hline & School & $N$ & Mean rank & $U$ & $p$ \\
\hline Successful performance & Waldorf & 51 & 83.37 & \multirow{2}{*}{2327.000} & 0.124 \\
& Traditional & 103 & 74.59 & & \\
\hline
\end{tabular}

Source: Authors of the thesis.

The first assumption focused on the verification of existence of statistically important differences in the achieved score for students of a traditional grammar school and those of a Waldorf grammar school reached successful performance. Mann-Whitney $U$ test values $(U=2327.000 ; p=0.124)$ presented in Table 2, did not confirm any statistically significant difference. Our second assumption was therefore not confirmed. The average ranking of the score, however, achieved a higher numerical value for pupils of a Waldorf Grammar School.

H2: There is a significant statistical difference in the achieved score of the need to avoid failure for pupils of traditional grammar schools and a Waldorf Grammar School.

Another possibility of the need to perform well is avoidance of failure. These tendencies are shown in Table 3. 
Table 3

Descriptive Table of Values for Students' Needs to Avoid Failure

\begin{tabular}{lllllll}
\hline & School & Sex & Min & Max & $M$ & SD \\
\hline \multirow{5}{*}{ Failure avoidance } & Waldorf & Girls & 7 & 25 & 16.86 & 4.786 \\
& & Boys & 6 & 24 & 14.09 & 5.145 \\
& Sum & & 6 & 25 & 15.67 & 5.086 \\
& Traditional & Girls & 9 & 28 & 21.53 & 4.306 \\
& & Boys & 1 & 29 & 17.94 & 4.427 \\
& Sum & & 9 & 29 & 19.65 & 4.707 \\
\hline
\end{tabular}

Source: Authors of thesis.

Table 3 shows descriptive values of pupils' tendency to avoid failure. The lowest need to avoid failure was shown by a student of a traditional grammar school with a value of 1 . On the other hand, the highest achieved value was 29. Waldorf grammar school students had an average value of 15.57 for this tendency with a variance being 5.086. For the traditional grammar school pupils the value was 19.65 with a variance being 4.707 .

Table 4

Level Comparisons for Failure Avoidance for WGS and TGS

\begin{tabular}{llrlll}
\hline & School & $N$ & Mean rank & $U$ & $p$ \\
\hline \multirow{2}{*}{ Failure avoidance } & Waldorf & 51 & 55.81 & \multirow{2}{*}{1520.500} & \multirow{2}{*}{0.000} \\
& Traditional & 103 & 88.24 & & \\
\hline
\end{tabular}

Source: Authors of the thesis.

Another assumption concerning performance motivation was focused on the existence of statistically important difference in the tendency to avoid failure for traditional grammar school pupils and those of a Waldorf Grammar School. Table 4, shows average level values for the tendency to avoid failure. Mann-Whitney $U$ test $(U=1520.500)$ confirmed this existence with the highest purpose $p=0.000$. The average rank value indicates highest tendency to avoid failure for students of traditional grammar schools (mean rank= 88.24). The average rank value for Waldorf grammar school students was 55.81. These findings show that assumption 3 was confirmed. The last researched area focused on the hierarchy of needs which motivate pupils to do their schoolwork. This hierarchy is shown in Figure 3.

Figure 3 displays a hierarchy of motivational factors of learning for traditional primary school and Waldorf primary school students. The primary motivational factor of the Waldorf grammar but also the traditional primary school is the need for a prospective target. Another dominant motivating factor for Waldorf school students is the need for personal development, after which the need to develop a positive relationship with their parents placed itself in the hierarchy. Traditional primary school students consider the need to create a positive relationship with their parents to be the second major motivational learning factor. The third most significant motivational factor for the traditional primary school students is the need for self-development. The least significant factor affecting the performance at the traditional primary school is the need to develop a positive relationship with the teacher.

Table 5 shows the order of motivational factors for students of both types of surveyed schools, according to a preference for different types of needs. We consider the first three motivational aspects and the last motivational aspect to be the most significant. Those are the ones we placed our focus on the most. We stated 
the answers to research questions examining the issue of hierarchy of motivational aspects for students in the next section.

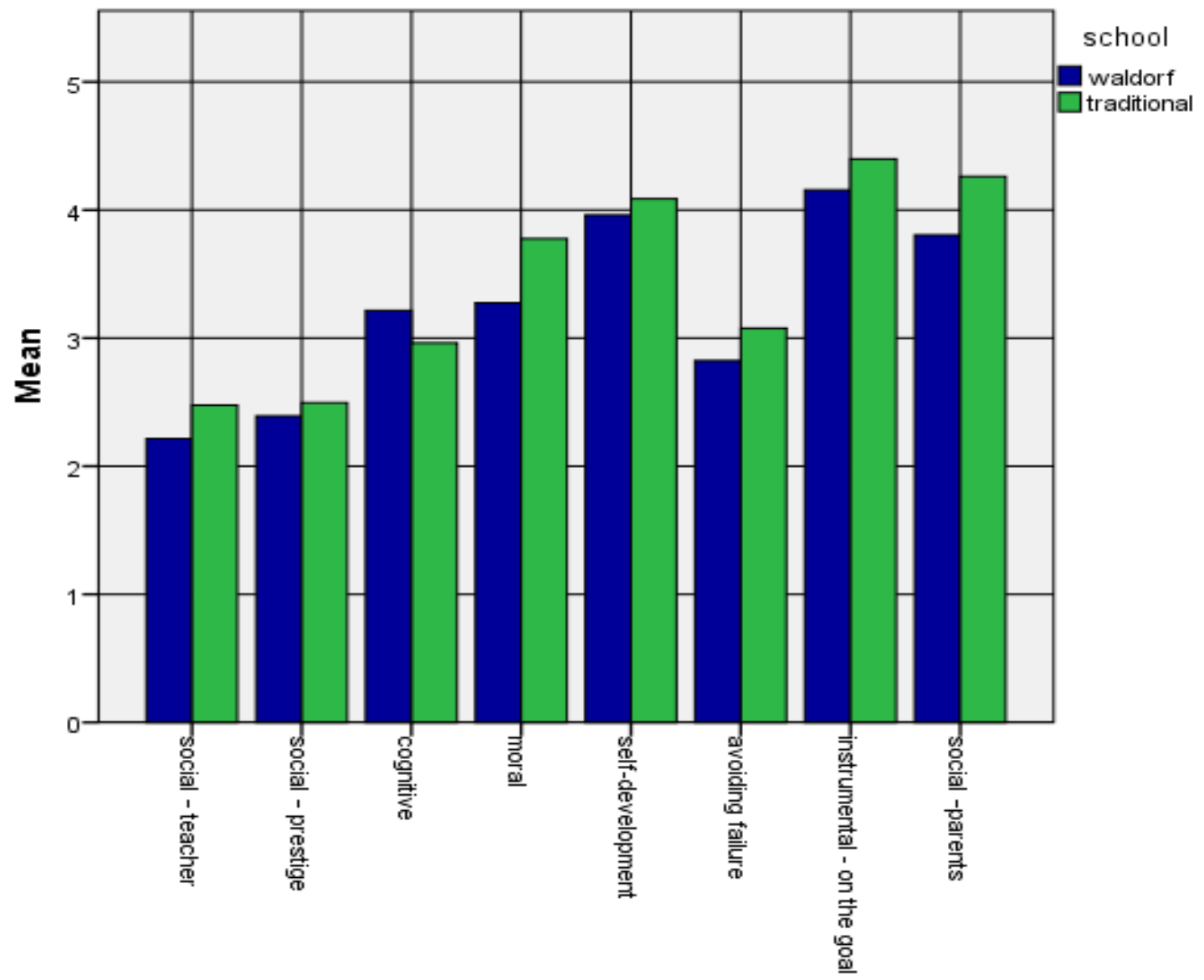

Figure 3. Motivational needs of traditional and Waldorf primary school students (Source: Authors of thesis).

Table 5

Hierarchy of WPS and TPS Students' Motivational Needs

\begin{tabular}{|c|c|c|c|c|c|c|c|}
\hline & \multicolumn{7}{|c|}{ School } \\
\hline & \multirow{2}{*}{ No. } & \multicolumn{3}{|c|}{ Waldorf } & \multicolumn{3}{|c|}{ Traditional } \\
\hline & & Motivational factor & $M$ & $S D$ & Motivational factor & $M$ & $S D$ \\
\hline \multirow{8}{*}{$\begin{array}{l}\text { Hierarchy of } \\
\text { motivational factors }\end{array}$} & 1. & Instrument & 4.16 & 1.155 & Instrument & 4.40 & 1.032 \\
\hline & 2. & Self-development & 3.96 & 1.264 & Soc. -parents & 4.26 & 1.129 \\
\hline & 3. & Soc. -parents & 3.80 & 1.281 & Self-development & 4.09 & 1.086 \\
\hline & 4. & Moral & 3.27 & 1.234 & Moral & 3.78 & 1.204 \\
\hline & 5. & Cognitive & 3.22 & 0.966 & Avoidance & 3.08 & 1.082 \\
\hline & 6. & Avoidance & 2.82 & 1.228 & Cognitive & 2.96 & 1.093 \\
\hline & 7. & Soc. -prestige & 2.39 & 1.097 & Soc. -prestige & 2.50 & 1.195 \\
\hline & 8. & Soc. - teacher & 2.22 & 2.39 & Soc. -teacher & 2.48 & 1.136 \\
\hline
\end{tabular}

Notes. instrument - the need to reach perspective goals; cognitive - the need for discovery; moral-moral need; self-development — the need for self-development; avoidance — the need to avoid failure; soc. -parents-social need — creation of positive relationships with parents; soc. -teacher-social need - creation of positive relationships with teachers; soc. -prestige-social need-gaining prestige.

Source: Authors of thesis. 
O.Q. 1: What is the hierarchy of motivational aspects for traditional primary school students?

For the students of traditional primary schools the need to pursue their perspective goals represents the most important motivational factor of their school performance. The second most important factor, that the students have identified as a source of motivation, is the need of students to receive a positive evaluation from their parents. The need to improve oneself is also being identified within the first three most often identified motivational factors. The need to build a positive relationship with their teacher is being identified by the students as the least important need.

O.Q. 2: What is the hierarchy of motivational aspects for Waldorf primary school students?

Similarly to traditional primary school students, the Waldorf primary school students have also identified the need to pursue their perspective goals as the primary motivational factor activating them to school performance. The need for self-improvement is also identified as a significant motivational factor. The trinity of the most important factors for Waldorf primary school students is topped by the need for maintaining good relationships with their parents. The students of

Waldorf primary school have also identified the need for receiving positive valuation from their teacher as the least important motivational factor for conducting tasks at school.

O.Q. 3: What is the difference in hierarchies of motivation sources between both types of schools?

From Table 5, it can be extrapolated that the hierarchy of needs of students for both types of schools is very similar. The most significant motivating factor and a factor that students in both types of schools identified as the least significant coincide. The most significant is the idea of achieving their perspective goals and the least important is the need to develop a positive relationship with the teacher. However, differences can be observed in the places the different factors have taken. In particular, the differences are observable in the preference between two pairs of aspects. The first pair are the needs located on the second and third partition of the hierarchy. These partitions place concern the needs identified as self-development and social, regarding the relationship with the parents. While the Waldorf school students identified their own self-development needs as a significant motivating factor, the traditional primary school students identified the need to develop a positive relationship with their parents as a more fundamental one. The second pair of motivating needs is being represented by the need for exploration and the need to avoid failure. These are the needs that placed on the fifth or sixth partition of the hierarchy in the hierarchy of motivational factors of both schools. Waldorf school students prioritized the need for exploration as a source of motivation to learn. Traditional primary school students identified the need to avoid failure as the more fundamental and significant factor. Students of both types of schools identified moral need as the fourth motivating factor. They have also both chosen the need for prestige among peers as the seventh out of eight motivational factors.

\section{Discussion}

The aim of our research was to compare the effect of traditional elementary school teaching and Waldorf primary school teaching on student's personality and motivation. The assumption that there are differences in the level of need to achieve a successful performance between the two primary school teaching styles was not confirmed. In situations where students have to present their own knowledge, greater need to avoid failure is experienced by the traditional primary school students. Results also pointed to the existence of a difference in motivational need hierarchies between both types of schools. The difference in the most important motivating factors and the least significant factors has not been identified by research. Interesting differences, however, 
occurred in the internal partitions of hierarchies. Students of both types of primary school teaching consider the reaching of their prospective goals to be the most motivating factor in gaining knowledge. The least motivating factor is the need to maintain positive relationships with their teachers. Waldorf school students, compared to students of the traditional school, prefer the need for discovery over the need to avoid failure, and the need to develop themselves over the need to learn in order to promote positive relationships with their parents. The moral need and the need for prestige holds an equally important position in the hierarchy of motivating factors. We will provide a more detailed discussion on individual research results in the following sections of the chapter.

\section{Performance Motivation}

The first factor we have focused on within our comparative research, was motivation of students. Specifically, there were two kinds of performance motivation being researched: the students need to successfully carry out the task, and the students' effort in avoidance of unsuccessful execution of tasks. According to Rýdl (1999, as cited in Alexovičová, 2007), the result of effects of principles of methods of the traditional primary school is the formation of extrinsic motivation for executing school tasks. The application of alternative methods in the Waldorf primary school, according to this author, purposefully forms intrinsic motivation. Therefore we assumed, that there will be a significant difference in efforts to achieve a successful performance and also in the need to learn in order to avoid failure between these two types of schools. The assumption that there is a significant difference in the effort to successfully perform a task was not significantly confirmed. We interpret this phenomenon by the fact that intrinsic motivation is affected by multiple determinants such as emotional stability (Mičková, 2015). Actual intrinsic motivation is formed on the basis of personal preconditions (Milová \& Blatný, 2012), but it is also considerably affected by the environment (Barandovská, 2015). Nevertheless, the data collected for our research have confirmed an existing difference in the students' tendencies in avoiding failure of statistically high importance. Traditional primary school students have rated this need as more fundamental motivating factor in their learning, compared to how Waldorf School students perceived this need. Waldorf School students were not achieving significantly higher values than traditional school students in any of the studied performance requirements. Authors (Grecmanová \& Urbanovská, 1996; Gorduličová \& Baloha, 2013) explain, that methods, that are being used in the process of Waldorf schools affects the formation of intrinsic motivation. Performance requirements are formed under the influence of external sources of motivation. Included in those are most of all grades (Čapek, 2014). At a Waldorf school the valuation of students is not done by grading in the first years. The teacher evaluates students verbally, while making sure to support the student even if their evaluation is not positive (Grecmanová \& Urbanovská, 1996). If the teacher points to the positive part of the students performance after criticising him and shows them support, it is probable that the student will not be trying to fight for the attention of his teacher by achieving good results. Ryan and Deci (2000) state in their auto determining theory, which the form the teacher uses for giving the task is having great effect on the forming of intrinsic and extrinsic motivation. The development of the intrinsic motivation is greatly supported if the student is given space for his own choice of a task he will be spending time on. According to Gorduličová and Baloha (2013), a free choice in the teaching process is one of the methods of Waldorf School. Rios (2007) tried to find out what methods Waldorf teachers were using to motivate students. The teachers of the Waldorf schools are also trying to motivate students by uttering verbal support using terms such as "excitement", "inspiration", "love", "joy", and "encouragement". 
Teachers also explain that educational curriculum is customized to the students abilities and changes in their development. This is making the learning process easier. Also their own creative abilities, that enable them to put together lessons in an interesting and fun way for students, have a direct effect on a intrinsically motivated performance by the student. Based on these findings, it can be assumed that the Waldorf school education is really designed for the formation of intrinsic motivation. John and Catherine-Fiske (1999, as cited in Wirz, 2007) have created an overview of studies of schools that are actively using artistic expression and creative activities in the education process. Based on this review, we have concluded that students in these schools are not learning to gain, or avoid incentives resulting from the fulfillment of school tasks. The source of their motivation is their own interest. Basencon, Fenouillet, Shankland (2015) also found a lower rate of external control motivation in students of Waldorf elementary schools compared to traditional primary school students. At the traditional primary school, grades are the basis of student's assessment (Zelina, 2000). Students receive negative assessments too. However a bad grade is perceived as a punishment. A person has a natural tendency to avoid punishment (Lokšová \& Lokša, 1999). It is especially frustrating for a child if despite their own effort they will still get bad grades (Čapek, 2014). They can get a feeling that they have little effect on the results and that they are learning only out of fear of failing a test (Weiner et al., 1981). The traditional school student meets these types of situations routinely. Therefore, one would expect that precisely these situations are responsible for the increased need of traditional school students to learn in order to avoid failure.

\section{Hierarchy of Needs}

As we have already suggested in the earlier part of the discussion, the hierarchy of motivational factors for students of both types of schools were very similar. Students generally considered the need to learn in order to achieve their future goals as the most important motivating factor. The result of our study is consistent with the results of the study conducted by Barqawi and Valovič (2015). In their study, students also designated the need to learn in order to achieve their future goals to be the most important motivating factor. This need begins to form in the student's later school age. The child ends primary schooling and reflects on its future (Durič, 1992). If it already has a clear idea of the type of high school it wants to attend and its future career, it may be aware that the knowledge being taught at that school will be needed for this profession. It is likely that the location of this need on the first level of the hierarchy is influenced by the mentality of adolescents. In terms of comparison, particularly interesting is the detailed insight into various aspects within the resulting hierarchy of students of the schools at hand.

The difference, however, was that the Waldorf school students identified the need for self-development as the second most significant factor, and the need to build a positive relationship with parents through good results as the third one. Students of the traditional primary school determined the position of these two needs in the hierarchy the other way round. The location of these two needs at the top tier of the hierarchy seems to be just a confirmation of Vagnerová (2008) description of motivation from a previous developmental stage. The child in this period comes up with the idea of a perfect performance which is accepted by parents. Its impact is likely to last in the traditional primary school students. However, the question is, why students of Waldorf primary school prefer the need for their own development. The preference of this need specifically may reflect one of the fundamental objectives of Waldorf schools, which is to educate students so that they are able to move the best in adult life. If the child grows up in the same spirit, it can internalise it so that it becomes one of the dominant motivational incentives. However, we also foresee that the root cause may be the school teaching 
methods. The teacher often structures the lesson in such a way that children get to learn about the regularities of various phenomena themselves. They seek information individually (Carlgren, 2013; Garduličová \& Baloha, 2013). It is therefore likely that such students become aware of the importance of subjects covered for their future sooner, than traditional primary school students teach directionally (Zelina, 1996). The fifth and sixth level of the hierarchy of motivational factors identified by the students in both kinds of schools was again very similar. Waldorf school students, however, placed the need for discovery in the fifth place and the need to avoid failure was left in the sixth. Traditional school pupils preferred the need to avoid failure. We believe this happens because of their fear to get a bad grade. On one hand, the pupils are trying to keep positive image of themselves and on the other they are trying to satisfy their need for positive evaluation. It seems that Waldorf Grammar School pupils are really motivated and so it can be concluded that they really have a more significant need to explore their surroundings. Pupils are verbally evaluated. A part of their evaluation is also teacher support (Grecmanová \& Urbanovská, 1966). This support most likely suggests that pupils are not so intensely stressed about failure and can focus on things they really want to learn about. Their least important factor was to have a positive relationship with their teacher. This compliance between students of both schools is probably because of the developmental period which students were going through. This suggests that students have a highly critical opinion of their teachers. The student does not consider his or her authorities critically. On the contrary, student tries to separate from it (Vágnerová, 2008). Steiner (1947) perceives a teenager as a mature personality, who is able to create his or her own opinions. We consider it important to refer to the fact that these pupils have achieved higher emotional intelligence, creativity and its factors, whether they were statistically significant or not. Their need to study in order to avoid failure in their presentations was significantly lower than for traditional grammar school pupils. On the other hand, their need to achieve success was comparable to the need of traditional grammar school pupils. The hierarchical comparison of pupils from both types of schools pointed at a tendency to prefer the need for self-development as a motivation factor. This means that they should be motivated from deep within. All three factors are more positive for the pupils of Waldorf grammar school than for traditional grammar school students. Internal motivation increases the child's interest, improves his or her creativity, leads to a better time management, puts less pressure on the student, improves emotional intelligence and increases self-confidence (Deci, Ryan, \& Williams, 1996). According to Batasencon et al. (2015), creativity level may affect a lot of factors. Especially forming and supporting personal wellbeing could achieve higher creativity levels. E. P. Torrance and J. P. Torrance (1973) believes that creative thinking is also supported by emotional intelligence. He furthermore concluded that the best way to expand children's creative thinking is to work with emotionality, cognitive functions and appropriate motivation. John and Catherine-Fiske (1999, as cited in Wirz, 2007) highlight, that learning in an environment with some sort of artistic expression, reversely affects students' motivation for learning. They found out that pupils study in this environment because it is actually interesting for them. Based on these findings it can be concluded that for higher values of emotional intelligence and creativity and it can be concluded that all these three factors are in fact responsible for motivation level.

\section{Limitations}

We have come across certain limitations during this research, however, not much attention was paid to them. One of the drawbacks was using a questionnaire as a data collection method. Although we did consider this method as the most appropriate, according to several specialists it is not so. 
Another limit was a research sample, which we chose since traditional schools are on a high level. It is questionable whether we would have got similar results if we had cooperated with more and especially other schools.

For a developmental support of Waldorf Grammar Schools in Slovakia, we considered it important to include a Slovakian sample in this research. In Slovakia, however, there is only one Waldorf grammar school of secondary education and this fact significantly affects any generalization.

Another limit could be the actions of teachers and parents on student's motivational aspects. Furthermore, we did not pay attention to the current wellbeing of students, which could have affected the collected data. Another negative factor could be that there was not much light in the rooms.

\section{Recommendations}

Based on the size of the research sample we would recommend to redo this research with a bigger sample, if Waldorf Grammar Schools in Slovakia were to expand. We would also like to note that the questionnaire also includes a whole range for evaluation of no motivation at all, which we have not used. It could again, create a more detailed motivational image for both types of schools.

\section{Future Intentions}

In future, we would pay more attention to emotional bonds, an upbringing style and individual's personality, which determine pupil's motivation either in alternative or traditional schools. According to our expectations, individual's success correlates with a positive emotional bond, upbringing style, which is dominated with open door approach. We believe that negative practices as punishments, humiliation, alteration or overload can lead to a decrease in motivation. It would be interesting to find out which personality traits determine student's motivation. Furthermore, in future we will examine the correlation between motivation and successful development of an individual. According to our findings, people with higher motivation will probably have a higher chance to successfully fit in society. We believe that people that are more open will evaluate their performance as more successful.

\section{References}

Alexovičová, T. (2007). Alternativne školstvo v kocke-1.čast’. Prešov: Metodicko-pedagogické centrum.

Barqawi, I., \& Valovič, J. (2015). Správa z merania dotazníkom DMŠ: Dotazník motivácie v škole. Bratislava: NúCEM.

Baranovská, A. (2015). Emotional intelligence and perfectionism as factors determining the rate of burn-out in primary and secondary school teachers. Canadian International Journal of Social Science and Education, 3, 428-443.

Besançon, M., Fenouillet, F., \& Shankland, R. (2015). Influence of school environment on adolescents' creative potential, motivation and well-being. Learning and Individual Differences, 43, 178-184.

Carlgren, F. (1993). Výchova ke svobodě: Pedagogika Rudolfa Steinera. Bratislava: SPN.

Č́áp, J. (1993). Psychologie výchovy a vyučování. Praha: Karolinum.

Čáp, J. (2001). Celkový způsob výchovy. In J. Čáp, \& J. Mareš (2001). Psychologie pro učitele (pp. 303-362). Praha: Portál.

Čapek, R. (2014). Odměny a tresty ve školni praxi kázeňské strategie, zásady odměňování trestáni hodnoceni a klasifikace, podpora a motivace žáki̊ (2 vyd. ). Praha: Grada.

Deci, E. L., Ryan, R. M., \& Williams, G. C. (1996). Need satisfaction and the self-regulation of learning. Learning \& Individual Differences, 8(3), 165.

Durič , L., \& Kol. (1992). Učitel’ská psychológia. Bratislava: SPN.

Gorduličová, A., \& Baloha, F. (2013). Škola, ktorej sme dali srdce. Bratislava: Parentes, Naša škola, 16(8), 66-68.

Grecmanová, H., \& Urbanovská, E. (1996). Waldorfská škola. Olomouc: Hanex.

Hrabal, V., Man, F., \& Pavelková, I. (1989). Psychologické otázky motivace ve škole. Praha: SPN. 
Hrabal, V., \& Pavelková, I. (2010). Jaký jsem učitel. Praha: Portál.

Hrabal, V. (1978). Příspěvek k rozboru motivace školního výkonu žáka z hlediska pedagogické psychologie. Pedagogika, 28(2), 195-208.

Hrabal, V. (1988). Jaký jsem učitel? Metody získáni poznatků o vlastni vzdělávací činnosti. Praha: Státní pedagogické nakladatelství.

Chvalová, V. (2014). Waldorfská škola a motivace ve vyučování: diplomová práca. České Budějovice: Jihočeská univerzita v Českých Budějovicích.

Ionova, O. M. (2013). The formation of person's health: Experience of Waldorf School. In Pedagogika, psihologia ta mediko-biologicni problemi fizicnogo vihovanna i sportu (Vol. 10, pp. 35-40). doi:10.6084/m9.figshare.775337.

Jurašková, K. (2004). Alternatívne vyučovanie na ZŠ a SŠ na Slovensku. Ružomberok: Edičné stredisko Pedagogickej fakulty.

Lokša, J., \& Lokšová, I. (1999). Pozornost, motivace, relaxace a tvořivost dětí ve škole. Praha: Portál.

Mičková, Z. (2015). Adolescence a projevování emocí v rodině. In Sapere Aude 2015: koncepty dneška: recenzovaný sborník př́spěvků vědecké konference s mezinárodní účastí (Vol. V., pp. 419-427). Hradec Králové: Magnanimitas.

Millová, K., \& Blatný, M. (2012). Vývoj člověka v kontextu společnosti procházející významnou změnou (tranzicí). In P. Halama, R. Hanák, \& R. Masaryk (Eds.), Sociálne procesy a osobnost' (na CD, pp. 96-101). Bratislava: Ústav experimentálnej psychológie SAV.

Nakonečný, M. (2004). Motivace lidského chování. Praha: Academi.

Pavelková, I. (2002). Motivace žáků k učeni: Perspektivni orientace žákủ a časový faktor v žákovské motivaci. Praha: Univerzita Karlova.

Pulicarová, T. (2015). Hodnocení školni práce a strachu ze školy žáků tradičných a vybraných alternativních škol: Diplomová práca. Brno: Masarykova univerzita.

Rios, J. (2007). Exploring Waldorf teacher's conceptions of motivation in the classroom. Cape Town: The Centre for Creative Education.

Rotter, J. B. (1966). Generalized expectancies for internal versus external control of reinforcement. Psychological Monographs, 80(1), 1-28.

Ryan, R. M., \& Deci, E. L. (2000). Self-determination theory and the facilitation of intrinsic motivation, social development, and well-being. Psychologist, 55(1), 68. doi:10.1037110003-066X.55.1.68.

Rybárová, E. (1992). Obdobie adolescencie. In L. Durič, \& Kol. (1992). Učitel'ská psychológia. Bratislava: SPN.

Sejčová, L. (2007). Motivácia žiakov na výkony. Bratislava: Album.

Steiner, R. (1947). Výchova ditěte s hlediska duchovní vědy. Praha: Anthroposofická společnost v ČR.

Torrance, E. P., \& Torrance, J. P. (1973). Is creativity teachable? Phi Delta Kappa Foundation Fastback 20.

Vágnerová, M. (2001). Kognitivni a sociální psychologie žáka základni školy. Praha: Karolinum.

Vágnerová, M. (2008). Vývojová psychologie I. Détství a dospíváni (p. 467). Praha: Karolinum.

Veselský, M. (2010). Motivácia žiakov učit’ sa. Teória a prax. Bratislava: Univerzita Komenského.

Weiner, B. et al. (1981). Social cognition in the classroom. Educational Psychologist, 18(2), 109-124. DOI:10.1080/00461528309529267.

Wirz, D. (2007). Výchova začina vztahem. Brno: Akademické nakladatelství CERM.

Zelina, M. (1996). Stratégie a metódy rozvoja osobnosti. Bratislava: IRIS.

Zelina, M. (2000). Alternativne školstvo. Bratislava: IRIS. 